\title{
PENGARUH KUALITAS TELUR TERHADAP SIFAT FISIK DAN SIFAT ORGANOLEPTIK SPONGE CAKE
}

\author{
(The effect of quality egg on a physical and organoleptic characteristic of \\ sponge cake)
}

\author{
Jora Linca Arbowatia ${ }^{a}$, Sri Mulyania, dan Antonius Hintono ${ }^{a}$ \\ aFakultas Peternakan dan Pertanian, Universitas Diponegoro, Semarang \\ * Penulis Korespondensi \\ Email: Joralinca@gmail.com
}

\begin{abstract}
The aim of this research to determine effect of egg quality on the flowering ability, stability of flowering ability, the morphology of crumb, and organoleptic characteristic. methode used in this research was experiential used Complete Random Design with a single factor experiment of egg quality, consisting of 3 groups is $T 1=$ egg quality grade $A A, T 2=$ egg quality grade $A$, and $T 3=$ egg quality grade $B$. Treatments were conducted seven times each. Data based on analysis of varians and followed by futher tests using the Duncan test at 5\% significance, data base of organoleptic is analysed with the kruskal wallis test and followed by mann-whitney test. The result of this research is the different us of quality of he eggs affect the stability of the cakes and the texture of cake. Egg quality grade $A$ is a most optimum ingredients to make a best sponge cake.
\end{abstract}

Keywords: Egg's quality, Sponge cake, Egg

\begin{abstract}
ABSTRAK
Tujuan dari penelitian ini untuk mengetahui pengaruh kualitas telur terhadap, daya kembang, stabilitas daya kembang, morfologi crumb, dan sifat organoleptis sponge cake. Metode yang digunakan dalam penelitian ini adalah secara eksperemental menggunakan Rancangan Acak Lengkap (RAL) dengan percobaan faktor tunggal yaitu kualitas telur yang terdiri dari 3 kelompok yaitu $T_{1}$ : kualitas telur grade AA ( $\mathrm{H}$ 80-90), $\mathrm{T}_{2}$ : kualitas telur grade $\mathrm{A}$ ( $\mathrm{HU}$ 60-71), $\mathrm{T}_{3}$ : kualitas telur grade $\mathrm{B}$ ( $\mathrm{HU}$ 50-59). Masing - masing perlakuan diulangi sebanyak 7 kali. Data hasil pengamatan dianalisis statistik dengan ANOVA (Analysis of Varian) dan dilanjutkan uji wilayah ganda (Duncan) dengan taraf signifikansi 5\%, sedangkan untuk data sifat organoleptis dianalisis dengan uji Kruskal-Wallis dan dilanjutkan dengan uji Mann-Whitney. Hasil dari penelitian ini bahwa penggunaan kualitas telur yang berbeda mempengaruhi stabilitas daya kembang cake dan tekstur cake. Telur grade A merupakan bahan paling optimum untuk pembuatan sponge cake yang berkualitas.
\end{abstract}

Kata kunci: Kualitas Telur, Sponge Cake, Telur

\section{PENDAHULUAN}

Cake merupakan salah satu produk pangan yang digemari banyak masyarakat semua kalangan, baik anak kecil, remaja, hingga orang tua. Banyak sekali jenis cake yang mulai dikembangkan mulai dari kreatifitas topping, tekstur, bentuk hingga formula yang bervariatif. Beberapa jenis cake yaitu chiffon cake, sponge cake, cotton 
cake dan angel cake. Perbedaan jenis cake hanya terletak pada metode pembuatannya. Jenis cake yang paling digemari salah satunya adalah sponge cake. Sponge cake adalah jenis kue bolu yang pembuatannya dengan dilakukan pengocokan gula dan telur hingga kental dan naik lalu penambahan bahan lain (bahan kering), kemudian dilakukan pemanggangan . Cara pembuatan yang mudah dan bahan juga tidak sulit dicari, mampu meningkatkan ketertarikan pada konsumen. Sponge cake adalah produk cake yang mengunakan bahan baku telur segar dalam jumlah banyak serta menggunakan sedikit margarine, tepung terigu, pengembang, dan gula pasir kemudian diolah dengan metode yang dinamakan sponge cake method (Hajrah et al.,2019). Salah satu bahan yang mempengaruhi hasil akhir kualitas sponge cake adalah telur. Telur merupakan bahan penting dalam pembuatan cake. Fungsi telur pada pembuatan cake adalah sebagai penambah volume pengembangan, memberi warna, memberi kelembaban, serta memberi tekstur lembut pada cake (Ningsih dan Farida, 2020). Telur memiliki beberapa grade kualitas dilihat dari Haugh Unit (HU) telur. Kualitas telur sesuai dengan nilai Haugh unit yaitu kualitas $A A$ dengan nilai $\mathrm{HU}>72$, kualitas $\mathrm{A}$ nilai $\mathrm{HU}$ pada kisaran 60-72, kualitas $\mathrm{B}$ dengan nilai $\mathrm{HU}$ 31-60, dan kualitas $\mathrm{C}$ dengan nilai $\mathrm{HU}<31$ (Suradi, 2006). Namun dalam pasaran kualitas telur masih sangat beragam dan tidak diketahui jelas pengelompokannya, sehingga mampu menjadikan hasil cake yang berbeda pula. Adanya telur yang semakin lama disimpan akan merubah sifat fungsional nya, sehingga akan memberikan hasil cake yang berbeda. Cake yang baik memiliki beberapa syarat karakteristik yaitu simetris, ketika semua sisi cake sama serta tidak berbentuk, warna cerah ataupun tidak terlalu coklat, volume sedang, tekstur cake tidak menggumpal, padat, halus dan permukaan halus dan lembut, memiliki rasa manis dan aroma harus khas cake (Ekayani, 2011). Maka dari itu diharapkan dengan adanya kualitas telur yang terbaik mampu menciptakan kualitas cake yang baik pula, sehingga bisa diterima di kalangan masyarakat. Tujuan dari penelitian ini untuk mengetahui pengaruh kualitas telur yang berbeda terhadap daya kembang, stabilitas daya kembang, morfologi crumb dan sifat organoleptis sponge cake.

\section{BAHAN DAN METODE}

\section{Bahan}

Bahan yang digunakan pada penelitian ini adalah 120 butir telur ayam ras coklat (kualitas telur AA, A, dan B), 1,6 kg tepung terigu, $300 \mathrm{~g}$ tepung maizena, $2 \mathrm{~kg}$ gula pasir $2 \mathrm{~kg}$ margarin dan $200 \mathrm{~g}$ emulsifier.

\section{Rancangan Percobaan}

Rancangan percobaan yang digunakan adalah Rancangan Acak Lengkap (RAL) dengan 3 perlakukan dan 7 kali pengulangan. Perlakuan yang diterapkan yaitu Kualitas Telur Grade AA dengan HU 80-90 ( $\left.T_{1}\right)$, Kualitas Telur Grade A dengan HU 60-71 ( $\left.T_{2}\right)$, Kualitas Telur Grade B dengan HU 50-59 $\left(\mathrm{T}_{3}\right)$.

\section{Prosedur Penelitian \\ Pemilihan Kualitas Telur Ayam}

Pengumpulan telur ayam ras kemudian disimpan selama 1 minggu, 2 minggu, dan 3 minggu. Untuk mendapat kualitas telur, maka telur ditimbang bobot telurnya dengan timbangan analitik dan ukur tinggi putih telur dengan deep micrometer. Pengukuran indeks haugh unit $(\mathrm{HU})$ dengan rumus :

$$
\text { HU: 100log }\left(h+7,57-1,7 . W^{0,37}\right)
$$

Keterangan : $\mathrm{h}$ : tinggi putih telur kental $(\mathrm{mm}), \mathrm{W}$ : berat telur $(\mathrm{g})$

\section{Pembuatan Sponge Cake}

Dilakukan dengan pengocokan gula 100 $\mathrm{g}$, emulsifier (SP) $10 \mathrm{~g}$ dan 3 butir telur dengan kualitas telur grade $A A, A$, dan $B$ hingga berbusa selama 10 menit menggunakan mixer, kemudian penambahan tepung terigu $75 \mathrm{~g}$ dan tepung maizena $15 \mathrm{~g}$ hingga tercampur rata, lalu ditambahkan margarin cair. Setelah adonan jadi, adonan masuk kedalam loyang yang 
sudah diolesi mentega, lalu di oven selama 30 menit dengan suhu $180^{\circ} \mathrm{C}$.

\section{Uji Parameter \\ Daya Kembang}

Metode pengukuran daya kembang dilakukan dengan adonan sebelum pemanggangan ditempatkan di loyang ukuran diameter $18 \mathrm{~cm}$ dengan tinggi awal adonan seragam yaitu $3 \mathrm{~cm}(\mathrm{~A})$. Setelah dilakukan pemanggangan, tinggi sponge cake setelah pemanggangan (B) diukur dengan menggunakan penggaris dengan alat bantu tusuk sate yang ditusukkan pada tengah cake, lalu dihitung dengan menggunakan persamaan sebagai berikut:

$$
\begin{aligned}
& \text { Daya Kembang }=\frac{B-A}{A} X 100 \% \\
& \text { Keterangan: } \\
& \text { A = Tinggi adonan sebelum } \\
& \text { pemanggangan } \\
& B=\text { Tinggi adonan setelah } \\
& \text { pemanggangan }
\end{aligned}
$$

\section{Stabilitas Daya kembang}

Metode pengukuran stabilitas daya kembang dilakukan dengan cara diukur menggunakan penggaris dengan bantuan tusuk sate yang ditusukkan pada bagian tengah cake kemudian dilakukan pengukuran tinggi setelah pemanggangan (B) dan tinggi cake setelah didiamkan selama 30 menit (C). Rumus stabilitas daya kembang menggunakan persamaan sebagai berikut:

Stabilitas Daya Kembang $=\frac{C}{B} X 100 \%$

Keterangan:

$$
\begin{aligned}
& \mathrm{B}=\text { Tinggi adonan setelah } \\
& \text { pemanggangan } \\
& \mathrm{C}=\text { Tinggi cake setelah didiamkan } \\
& \text { selama } 30 \text { menit }
\end{aligned}
$$

\section{Morfologi Crumb}

Pengamatan morfologi crumb dilakukan dengan metode pemotretan. Sponge cake yang telah diiris menjadi dua bagian kemudian dilakukan pemotretan. Analisis dilakukan dengan membandingkan morfologi crumb dengan indera penglihatan bagian pori -pori crumb dan bentuk matriks crumb pada setiap perlakuan.

\section{Uji Organoleptis}

Uji organoleptik dilakukan dengan uji mutu organoleptik dan uji hedonik. pengujian dilakukan oleh 25 panelis dengan melakukan pengisian form penilaian terhadap sifat oranoleptik dan hedonik pada sponge cake. pengisian form penilaian menggunakan metode skoring dengan skor 1-5. Format yang digunakan meliputi penilaian warna, tekstur, aroma, dan overall.

\section{Analisis Data}

Data uji daya kembang dan stabilitas daya kembang di analisis dengn ANOVA (Analysis of Varians), adanya pengaruh terhadap daya kembang dan stabilitas daya kembang maka dilanjut uji Wilayah Ganda (Duncan). Sedangkan data sifat organoleptis diuji dengan uji kruskal wallis, dan untuk tekstur terdapat penaruh maka dilanjut dengan uji Mann-Whitney.

\section{Daya Kembang \\ HASIL DAN PEMBAHASAN}

Hasil pengukuran daya kembang diperlihatkan pada Tabel 1. tampak bahwa penggunaan kualitas telur yang digunakan dalam pembuatan sponge cake berpengaruh nyata $(\mathrm{P}<0,05)$. Daya kembang tertinggi pada kualitas telur grade B (HU 50-59) yaitu $117,66 \%$, serta daya kembang terrendah pada perlakuan kualitas telur AA (HU 80-90) yaitu 96,18\%. Daya kembang cake dipengaruhi oleh bahan yang digunakan, salah satunya adalah telur. Adonan akan mengalami peningkatan volume ketika daya buih yang dihasilkan tinggi saat proses mixing. Daya buih terbentuk karena ketika pengocokan, ikatan-ikatan protein ovomucin-lysozyme terbuka yang menyebabkan rantai panjang 
Jora Linca Arbowati et al., 2021.

Tabel 1. Hasil Pengujian Daya Kembang Sponge Cake

\begin{tabular}{ccc}
\hline Kualitas Telur & Daya Kembang & Stabilitas Daya Kembang \\
\hline AA & $96.18 \pm 12.38^{\mathrm{a}}$ & $88.26 \pm 5.4^{\mathrm{b}}$ \\
A & $106.18 \pm 13.25^{\mathrm{ab}}$ & $79.97 \pm 4.7^{\mathrm{a}}$ \\
B & $117.66 \pm 16.85^{\mathrm{b}}$ & $73.74 \pm 6.7^{\mathrm{a}}$ \\
\hline
\end{tabular}

Keterangan :

Data ditampilkan sebagai nilai rerata dari 7 ulangan \pm SD

$\mathrm{T}_{1}-\mathrm{T}_{3}=$ Penggunaan kualitas telur grade AA (HU 80-91), A (HU 60-71), B (50-60)

*Superscript yang berbeda pada kolom yang samavmenunjukkan perbedaan nyata $(\mathrm{P}<0.05)$

protein kemudian membentuk gelembung gas dan volume buih bertambah. Hal ini sesuai dengan pendapat Sarofa dan Dewi (2019) yang menyatakan bahwa volume buih bertambah ketika udara mulai masuk ke dalam putih telur yang ikatan proteinnya mulai terbuka dan rantai protein semakin panjang akibat pengocokan. Volume buih yang meningkat menandakan bahwa daya buih telur juga semakin tinggi. Perlakuan kualitas telur B (HU 50-59) menjadi perlakuan yang memiliki daya kembang tertinggi, hal ini disebabkan karena memiliki Haugh Unit (HU) rendah dimana hal itu akan membuat daya buih semakin besar karena kondisi protein pada putih telur sudah mengurai menjadi ikatan lebih panjang. Hal ini sesuai dengan pendapat Triawati (2013) yang menyatakan bahwa telur yang encer akan lebih cepat berbuih, hal ini disebabkan karena ikatan protein terbuka yang berakibat memudahkan mengikat udara dan berbuih jadi ketika pengocokan adonan akan mengalami pengembangan. Sedangkan pada kualitas telur AA (HU 80-90) dan kualitas telur A (HU 60-71) masih memiliki kualitas yang bagus terutama pada proteinnya yang berikatan pendek, sehingga daya buih yang dihasilkan rendah ketika dikocok dengan waktu yang sama dibanding kualitas telur B (50-59). Hal ini sesuai dengan pendapat Sudjatinah dan Sampurno. (2019) bahwa daya buih semakin tinggi, ketika penyimpanan semakin lama.

\section{Stabilitas Daya Kembang}

Hasil dari pengujian stabilitas daya kembang pada Tabel 1. tampak bahwa kualitas telur berpengaruh nyata $(P<0,05)$ terhadap stabilitas daya kembang sponge cake. bahwa stabilitas daya kembang sponge cake pada kualitas telur AA (HU 8090), A (HU 60-71) dan B (50-59) masing masing yaitu $88,26 \%, 79,97 \%$ dan 73,74 $\%$. Stabilitas daya kembang tertinggi adalah perlakuan kualitas telur AA sebesar 88,26 $\%$, Stabilitas daya kembang yang tinggi menandakan cake mampu mempertahankan volume cake setelah pemanggangan. Stabilitas daya kembang tinggi disebabkan karena struktur yang terbentuk kuat serta buih yang rapat dan seragam. Hal ini sesuai dengan pendapat Imami dan Sutrisno (2019) yang menyatakan bahwa buih telur yang sudah dikocok berinteraksi dengan komponen lain sehingga adonan menjadi terbentuk rangka cake yang kuat. Ovomucin pada telur yang masih baik akan membantu mempertahankan buih yang terbentuk pada cake sehingga volume yang sudah meningkat tidak mudah menyusut. Hal ini sesuai dengan pendapat Thohari et al. (2020) yang menyatakan bahwa adanya ovomucin yang belum pecah akan menghasilkan daya buih yang rendah namun mampu mempertahankan volume buih yang terbentuk karena ikatan nya masih kuat. Perlakuan kualitas telur B (HU 50-59) mengalami penurunan volume paling besar, dimana kandungan protein yang berikatan dengan bahan lain tidak mampu mempertahankan volume yang terbentuk. Hal ini disebabkan karena ovomucin yang mulai berubah kualitasnya atau tidak kuat untuk mempertahankan matriks yang terbentuk. Telur yang semakin lama disimpan akan mengalami penurunan kualitas termasuk ovomucin. Hal ini sesuai dengan pendapat Harmayanda et al. (2016) yang menyatakan bahwa haugh unit yang 
Tabel 2. Hasil Uji Organoleptik Sponge Cake

\begin{tabular}{ccccc}
\hline Kualitas Telur & Warna $(\mathrm{ns})$ & Tekstur & Aroma $(\mathrm{ns})$ & Overall $(\mathrm{ns})$ \\
\hline AA & $2.50 \pm 0.81$ & $3.00 \pm 0.86^{\mathrm{b}}$ & $4.00 \pm 0.95$ & $3.50 \pm 0.90$ \\
A & $3.48 \pm 0.77$ & $4.00 \pm 0.76^{\mathrm{a}}$ & $3.60 \pm 0.81$ & $3.84 \pm 0.68$ \\
B & $3.64 \pm 2.12$ & $3.16 \pm 0.70^{\mathrm{ab}}$ & $3.56 \pm 0.70$ & $3.50 \pm 1.41$ \\
\hline
\end{tabular}

Keterangan :

Data ditampilkan sebagai nilai rerata dari 7 ulangan $\pm \mathrm{SD}$

$\mathrm{T}_{1}-\mathrm{T}_{3}$ = Penggunaan kualitas telur grade AA (HU 80-91), A (HU 60-71), B (50-59)

*Superscript yang berbeda pada kolom yang sama menunjukkan perbedaan nyata $(\mathrm{P}<0.05)$

semakin kecil menandakan telur sudah mulai mengalami penurunan kualitas selama penyimpanan, walau masih dalam kondisi baik.

\section{Morfologi Crumb}

Tekstur pada cake dapat dilihat dari morfologi crumb, hasil pengamatan morfologi crumb diperlihatkan pada Gambar 1. tampak bahwa kualitas telur AA (HU 8090), A (HU 60-71) dan B (HU 50-59) memiliki struktur crumb yang rapat pada pori - pori struktur cake dan seragam.

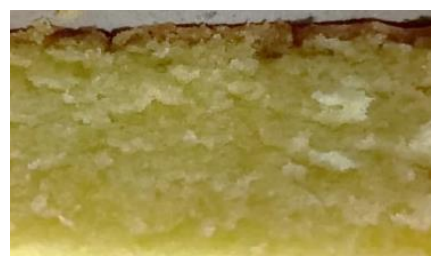

$\left(\mathrm{T}_{1}\right)$

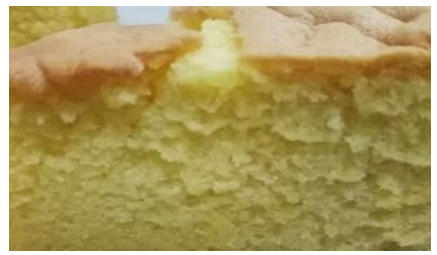

$\left(T_{2}\right)$

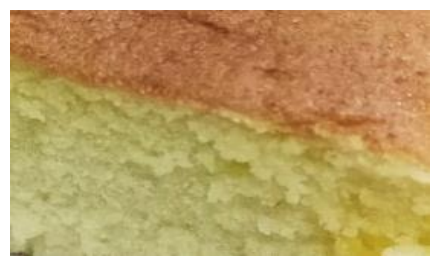

$\left(T_{3}\right)$

Gambar 1. Hasil morfologi crumb sponge cake
Hal ini dikarenakan adonan pada sponge cake mampu menahan gas yang terperangkap sehingga membuat pori - pori crumb menjadi lebih rapat dan seragam. Hal ini sesuai dengan pendapat Budi et al. (2019) yang menyatakan adonan yang baik dalam menahan gas yang terperangkap akan membuat pori - pori crumb rapat dan seragam. Hal ini disebabkan terbentuknya daya buih yang cukup besar sehingga menghasilkan matrix gel cake yang semakin kecil sehingga ketika pemanggangan matriks gel yang terbentuk akan padat dan seragam. Buih yang terbentuk akan membentuk pori - pori ketika dipanggang. Hal ini sesuai dengan pendapat Sipahelut et al. (2017) yang menyatakan bahwa selama pengocokan menghasilkan buih yang akan membentuk struktur pori - pori cake. Sponge cake kualitas telur AA (HU 80-90) memiliki pori -pori cake lebih besar dibanding sponge cake kualitas telur A ( $\mathrm{HU}$ 60-71) dan kualitas telur B (HU 50-59). Hal ini disebabkan karena buih yang dihasilkan sedikit dan partikel buih belum seragam dan kecil. Semakin sedikit buih dan air yang terikat saat pengadukan yang dihasilkan dalam pengocokan akan mempengaruhi hasil pori - pori crumb saat dipanggang, sehingga semakin tidak mudah berikatan antara protein telur, gluten tepung terigu hingga bahan lain akan mempengaruhi hasil crumb menjadi tidak stabil, tidak seragam dan kasar.

\section{Sifat Organoleptis}

Hasil uji organoleptis diperlihatkan pada Tabel 2. tampak bahwa kualitas telur memiliki pengaruh nyata terhadap tekstur 
sponge cake, namun tidak berpengaruh nyata terhadap warna, rasa, aroma dan overall.

\section{Warna}

Berdasarkan parameter warna bahwa penggunaan kualitas telur berbeda tidak berpengaruh nyata $(P<0,05)$ terhadap sponge cake dengan hasil nilai rerata 2,50 3,64 (kurang cerah - kekuningan). Warna kuning yan dihasilkan pada cake disebabkan adanya telur, dimana kuning telur yang mengandung pigmen warna lutein dan betakaroten. Hal ini sesuai dengan pendapat Widiantara (2018) yang menyatakan bahwa beberapa pigmen warna pada kuning telur mampu memberikan warna pada cake yaitu lutein, santofil, betakaroten, dan kriptosantin. Saat pemanggangan akan terjadi reaksi maillard, reaksi antara asam amino dari protein dengan gula pereduksi secara nonenzimatis sehingga timbul warna kekuningan. Hal ini sesuai dengan pendapat Vriyanie dann Sutrisno (2019) yang menyatakan bahwa reaksi maillard terjadi ketika pemanggangan adonan, hal itu dapat menyebabkan warna cake cenderung kekuningan.

\section{Aroma}

Berdasarkan parameter aroma bahwa penggunaan kualitas telur berbeda tidak berpengaruh secara nyata $(P<0,05)$ terhadap sponge cake dengan nilai rerata 3,56 - 4,00 (agak harum-harum). Aroma terbentuk ketika reaksi maillard saat pemanggangan terjadi penguapan sebagian senyawa - senyawa volatile dari bahan. Hal ini sesuai dengan pendapat Miftaul et al. (2017) yang menyatakan bahwa selama pemanggangan terjadi penguapan senyawa volatile yang membentuk aroma cake dari menguapnya sebagian bahan - bahan cake. Terbentuk interaksi antara asam amino dari protein dan gula pereduksi akan menghasilkan beberapa zat khas aroma harum. Kemudian lemak akan teroksidasi ketika dipanaskan sehingga sebagian dari zat yang aktif akan bereaksi dengan peptida dan asam amino sehingga timbul aroma khas saat pemanggangan. Hal ini sesuai dengan pendapat Armila et al. (2019) yang menyatakan bahwa selama pemanggangan protein terdenaturasi menjadi asam amino, asam amino akan bereaksi dengan gula hingga menimbulkan aroma, juga terjadi oksidasi lemak yang sebagian zat akan berinteraksi dengan asam amino dan lipida sehingga aroma khas keluar.

\section{Tekstur}

Berdasarkan parameter tekstur bahwa penggunaan kualitas telur berbeda memiliki pengaruh secara nyata $(P<0,05)$ terhadap sponge cake dengan nilai rerata $3,00-4,00$ (agak lembut-lembut). Tekstur yang dihasilkan kurang lembut dikarenakan pori pori yang terbentuk kurang rapat dan tak seragam. Pembentukan gelembung buih yang tidak optimal dimana kondisi putih telur yang berbeda juga akan mengakibatkan hasil buih berbeda, sehingga matriks gel yang terbentuk tidak seragam serta membuat lapisan yang tidak elastis dan mudah pecah sehingga ketika cake matang akan membentuk tekstur remahan. Hal ini sesuai dengan pendapat Yunieta dan Sutrisno (2019) yang menyatakan bahwa volume buih yang menurun dan tidak kuat akan mengakibatkan pengembangan menurun serta akan menjadikan struktur cake menjadi tidak seragam sehingga tekstur cake menjadi lebih mudah pecah dan kurang lembut. Adonan cake yang mampu mempertahankan stabilitas daya kembangnya akan menghasilkan cake yang seragam dan volume tidak mengempis sehingga menjadikan cake padat. Cake yang terlalu padat dan tidak seragam akan menghasilkan aftertaste yang seret ketika dimakan.

\section{Overall}

Berdasarkan parameter Overall dapat diketahui bahwa penggunaan kualitas telur yang berbeda tidak berpengaruh nyata $(P<0,05)$ terhadap sponge cake dengan rerata penilaian overall yaitu $3,50-4,00$ (agak suka hingga suka). Penilaian terhadap overall cake dilihat dari keseluruhan rasa suka oleh panelis 
terhadap cake mulai dari rasa, warna, tekstur, dan aroma. Sponge cake dengan kualitas telur AA (HU 80-90), A (HU 60-71) dan $B$ (HU 50-59) disukai karena memiliki tekstur yang rapat sehingga lembut ketika dimakan, selain itu dari segi warna, rasa, dan aroma masih disukai juga oleh panelis. Sponge cake yang akan digemari panelis cenderung warna cerah kekuningan, rasa manis, aroma khas cake, dan tekstur lembut dan empuk. Hal ini sesuai dengan Rohmah (2019) yang menyatakan bahwa cake yang baik memiliki warna cerah, rasa manis, aroma khas cake, tekstur empuk serta lembut jika digigit sehingga bisa dinikmati. Ketika panelis mampu menikmati sponge cake setiap perlakuan berarti sponge cake bisa diterima oleh konsumen.

\section{KESIMPULAN}

Kualitas telur yang digunakan dalam pembuatan sponge cake berpengaruh terhadap daya kembang, stabilitas daya kembang hingga tekstur, tetapi tidak berpengaruh terhadap warna, aroma, rasa dan overall sponge cake. Penggunaan kualitas telur A merupakan bahan yang paling optimum untuk pembuatan sponge cake yang berkualitas.

\section{DAFTAR PUSTAKA}

Armila, F., R. Rahmatu dan G. S. Hutomo. 2019. Karakteristik mutu fisikokimia dan organoleptik greenies cake daun kelor (Moringa oleifera L.). Jurnal agrotekbis. 7(4):1-10.

Budi, N. S., Y. Praptiningsih dan M. Maryanto.2019. Karakteristik cake yang dibuat dengan subtitusi campuran tepung pisang batu (Musa balbisiana colla) dan ubi jalar kuning (Ipomea batatus L.). Jurnal Berkala IImiah Pertanian.2(2):56-60. https://doi.org/10.19184/bip.v2i2.16170

Ekayani, I. A. P. H. 2011. Efisiensi penggunaan telur dalam pembuatan sponge cake. Jurnal Pendidikan

Teknologi dan Kejuruan, 8(2): 59-74. http://dx.doi.org/10.23887/jptk-

undiksha.v8i2.2853

Hajrah, N. A., A. Hintono dan V.P. Bintoro, V. P. 2019. Daya kembang, kadar air, morfologi crumb dan mutu organoleptik sponge cake yang dibuat dengan penambahan enzim g-4 amilase. Jurnal Teknologi Pangan, 3(2):7-12.

Harmayanda, P. O. A., D. Rosyidi dan O.Sjofjan. 2016. Evaluasi kualitas telur dari hasil pemberian beberapa jenis pakan komersial ayam petelur. Journal of Environment and Sustainable Development, 7(1).25-32.

Imami, R. H dan A. Sutrisno. 2019. Pengaruh proporsi telur dan gula serta suhu pengovenan terhadap kualitas fisik, kimia, dan organoleptik pada bolu bebas gluten dari pasta ubi kayu (Manihot Esculenta). Jurnal Pangan dan Agroindustri. $\quad 6(3): 89-99$. http://dx.doi.org/10.21776/ub.jpa.2018.0 $\underline{06.03 .10}$

Miftaul, I., R. Rauf dan E. N. Widyaningsih. 2017. Tingkat kekerasan dan daya terima biskuit dari campuran tepung jagung dan tepung terigu dengan volume air yang proporsional. Jurnal kesehatan. $\quad$ 10(2): 83-93. https://doi.org/10.23917/jurkes.v10i2.55

\section{$\underline{37}$}

Ningsih, Y dan A. Faridah . 2020. Pengaruh penggunaan jenis lemak terhadap kualitas sponge cake. Jurnal Kapita Selekta Geografi. 3(1): 1-9. https://doi.org/10.24036/ksgeo.v3i1.372

Rohmah, M. 2019. Diversifikasi tepung dalam pembuatan cake terhadap kesukaan konsumen. Jurnal IImiah Pendidikan Kesejahteraan Keluarga.4(2): 131-136. 
http://dx.doi.org/10.30738/keluarga.v4i2. $\underline{5172}$

Sarofa, U dan W.L.P Dewi. 2019. Karakteristik marshmallow dari kulit pisang raja (musa textilia): kajian konsentrasi gelatin dan putih telur. Jurnal Teknologi Pangan. 13(1): 20-27.

https://doi.org/10.33005/itp.v13i1.1505

Sipahelut, S. G., G. Tetelepta dan J. Patty. 2017. Kajian penambahan minyak atsiri dari daging buah pala (myristica fragranshoutt.) pada cake terhadap daya terima konsumen. Jurnal Sains dan Teknologi Pangan. 2(2):486-495.

Sudjatinah, U.F.F dan A. Sampurno. 2019. Pengaruh perbedaan lama penyimpanan pada suhu ruang terhadap sifat fisik, kimia, dan fungsional protein telur ayam ras. Skripsi. Universitas Semarang. Semarang. https://repository.usm.ac.id/

Suradi, K. 2006. Perubahan kualitas telur ayam ras dengan posisi peletakan berbeda selama penyimpanan suhu refrigerasi. Jurnal Ilmu Ternak. 6(2):136139.

\section{https://doi.org/10.24198/jit.v6i2.2282}

Thohari, I., F.Jaya dan N. A. R. Ajeng. 2020. Pengaruh penambahan asam asetat terhadap sifat fungsional albumen telur itik. Jurnal Teknologi Hasil Peternakan. 1(1): 25-33. https://10.24198/ithp.v1i1.23977

Triawati, N. 2013. Evaluasi Sifat Putih Telur Ayam Pasteurisasi Ditinjau Dari Daya Buih, Stabilitas Buih, Daya Koagulasi Dan Daya Kembang Sponge Cake (Doctoral dissertation, Universitas Brawijaya). http://repository.ub.ac.id/id/eprint/13687 $\underline{8}$

Widiantara, T.2018. Kajian perbandingan tepung kacang koro pedang (Canavalia ensiformis) dengan tepung tapioka dan konsentrasi kuning telur terhadap karakteristik cookies koro. Jurnal Pasundan Food Technology. 5(2): 146153.

http://dx.doi.org/10.23969/pttj.v5i2.1045

Yunieta, M dan A. Sutrisno. 2019. Penggunaan pasta ubi kayu (Manihot esculenta Crantz) sebagai bahan baku pembuatan cake. Jurnal Pangan dan Agroindustri. $\quad$ 6(2): $\quad$ 1-12. http://dx.doi.org/10.21776/ub.jpa.2018.0 06.02 .1

Zhou, W dan N. Therdthai. 2008. Heat and mass transfer during baking of sweet goods in book: Food engineering aspects of baking sweet goods. CRC Press. New York. 